\title{
Physicochemical Profiles and Water Quality Indices of Surface Waters Collected from Falcorp Mangrove Swamp, Delta State, Nigeria
}

\author{
1* ODIGIE, O; ${ }^{2}$ OLOMUKORO, JO \\ ${ }^{{ }^{*} 1}$ Department of Biological Sciences, Faculty of Science, Benson Idahosa University, Benin City, Edo State, Nigeria \\ ${ }^{2}$ Department of Animal and Environmental Biology, Faculty of Life Sciences, University of Benin, Benin City, Edo State, Nigeria \\ *Corresponding Author Email: Oodigie@biu.edu.ng; Tel: +234(0)8106234990
}

\begin{abstract}
Surface water samples were collected at a frequency of once monthly for a period of 18 months; February 2013- July 2014, from several points on the Falcorp mangrove swamp, Ijala, Warri, Delta State. The abstracted samples were subjected to several physical and chemical analyses which were conducted in accordance with referenced procedures. The recorded data were subjected to statistical analysis and multivariate analysis using Microsoft excel, SPSS version 16.0 and PAST respectively. There was no significant difference $(P>0.05)$ across the stations; Stations 1, 2, 3, 4 and 5 respectively for $\mathrm{pH}$, Temperature, Electrical conductivity, DO, $\mathrm{BOD}_{5}$, TSS, Turbidity, Chloride, Salinity, Sulphate, Nitrate, Hardness, $\mathrm{Ca}, \mathrm{Ma}, \mathrm{Zn}, \mathrm{Cd}$ and $\mathrm{Pb}$. There were significant difference $(P<0.05)$ across the 5 stations for the following parameters; TDS, Bi-carbonate, Phosphate, Fe and $\mathrm{Cu}$. The mean concentrations of most of the physical and chemical parameters in the surface water with the exception of $\mathrm{pH}$ were below acceptable WHO limits for portable water. The water quality index (WQI) at stations 1, 2, 3, 4 and 5 ranged from 8.45-24.9, 8.3123.95, 8.36-16.26, 8.24-10.11 and 8.43-23.58 respectively. The Principal component analysis (PCA) of the data sets yielded 35 variables under 22 components with Eigenvalues $<1$ (PC1-PC6) and >1 (PC7-PC22). There was a positive correlation between $\mathrm{pH}$, water temperature, TDS, EC, TSS, turbidity, $\mathrm{Cl}, \mathrm{HCO}_{3}$, salinity, $\mathrm{SO}_{4}$, hardness, $\mathrm{Ca}, \mathrm{Mg}$, and $\mathrm{Cd}$ whilst a negative relationship existed between $\mathrm{DO}, \mathrm{BOD}_{5}, \mathrm{PO}_{4}, \mathrm{NO}_{3}, \mathrm{Fe}, \mathrm{Zn}, \mathrm{Cu}$ and $\mathrm{Pb}$ respectively.
\end{abstract}

\section{DOI: https://dx.doi.org/10.4314/jasem.v24i2.23}

Copyright: Copyright $\mathbb{C} 2020$ Odigie and Olomukoro. This is an open access article distributed under the Creative Commons Attribution License (CCL), which permits unrestricted use, distribution, and reproduction in any medium, provided the original work is properly cited.

Dates: Received: 16 November 2019; Revised: 11 January 2020; Accepted: 22 February 2020

Keywords: Physicochemical, surface water, Falcorp, Mangrove swamp

Coastal ecosystems such as coral reefs, mangroves and wetlands are amongst the world's richest storehouses of biological diversity and primary productivity. Mangrove habitats are wide spread mostly in the Nigerian Niger Delta Region. They play an important ecological role while providing a variety of services for human well beings. The benefits obtained from these thriving mangrove ecosystems are quite broad and encompass a variety of economic, environmental and social aspects, including carbon sequestration for combating global warning. Field et al. (1998) reported that mangroves are known to function as a critical habitat for a plethora of terrestrial (e.g., bird colonies) and aquatic species (e.g., spawning, feeding and rearing habitats for many fish species. Mangroves are also known to play a significant role in the stabilization of sediments and the control of shoreline erosion through the entrapment of particulate matter and binding soil particles (Furukawa et al., 1997). Mangroves forests are composed of a relatively small number of tree and shrub plant species unlike other tropical forest. Species of mangrove forest are specially adapted to fluctuating salinity and are capable of living in anoxic muddy sediments. Mangrove vegetation composition is controlled primarily by hydrology, geography and climate of the region. Plant morphological adaptations such as aerial roots facilitate life on and in the inter-tidal zone. Pollution of mangrove and river systems can be attributed to a variety of human activities which range from large-scale agriculture and industry to everyday behavior, such as driving cars and fertilizing lawns. Large quantities of pollution often enter freshwater systems from point sources, such as industrial or municipal sewage outflows. However, nonpoint source pollution is far more significant in many cases also airborne pollutants can enter the atmosphere and travel long distances, entering lakes and waterways in otherwise pristine locations. Pollutants dissolved in runoff from the surrounding landscape may account for the greatest source of pollution in many freshwater ecosystems. Falcorp mangrove swamp has a direct interphase with the rainforest zone. It is a natural ecological site that serves as a research centre, even though not functioning, botanical garden, tourist and conservation site etc. The location however is sited behind the Warri Refinery and Petrochemical Company and this has raised many questions as to a possible pollution linkage from both point and nonpoint sources. This is because of refining activities,

*Corresponding Author Email: Oodigie@biu.edu.ng; Tel: +234(0)8106234990 
which includes those carried out within the refinery and illegal refining activities around. This could pose a threat to the environmental integrity of the total ecosystem.

The aim of this study was to investigate the physicochemical, heavy metal and PAHs profiles of surface water collected from Falcorp Mangrove Swamp, Ijala, Warri, Delta State, Nigeria.

\section{MATERIALS AND METHODS}

The Study Area: Falcorp mangrove swamp is located in Warri south Local Government Area of Delta State Nigeria. It is situated off the Warri refinery and petrochemical company jetty road, just behind the refinery. It falls within the mangrove swamp ecological zone but also has a direct interphase with the rainforest ecological zone. It lies on longitude $\left(005^{0} 41.1 \mathrm{E}, 005^{0} 57.4 \mathrm{E}\right)$ and latitudes $\left(05^{0} 18.3 \mathrm{~N}\right.$, $\left.05^{0} 84.5 \mathrm{~N}\right)$. The water channel within the protected area of the mangrove swamp is fed by water from surrounding creeks, rivers and surface runoffs from neighboring communities within the Ijala area.

Description of Sampling Stations and sample collection: Five stations were designated for this study. Each of this station was approximately 600 meters apart from each other. Station 1(Longitude $005^{\circ} 42.213^{\prime} \mathrm{E}$ and Latitude $\left.05^{\circ} 18.506^{\prime} \mathrm{N}\right)$, Station 2 (Longitude $005^{\circ} 41.4^{\prime} \mathrm{E}$ and Latitude $05^{\circ} 18.61^{\prime} \mathrm{N}$ ), and Station 3 (Longitude $005^{\circ} 42.65^{\circ} \mathrm{E}$ and Latitude $05^{\circ} .33 .50^{\circ} \mathrm{N}$ ) where located within the protected area of the Falcorp mangrove along the water channel, while Station 4 (Longitude $005^{\circ} 55.27^{\prime} \mathrm{E}$ and Latitude $05^{\circ} 66.202^{\prime} \mathrm{N}$ ) and Station 5 (Longitude $005^{\circ} 48.94^{\prime} \mathrm{E}$ and Latitude $05^{\circ} 69.715^{\prime} \mathrm{N}$ ) were located in Ifie creek which is linked to the water channel of the Falcorp mangrove.

Water samples were collected from the five sampling points once a month for a period of 18 months using $250 \mathrm{ml}$ sterile sampling bottles dipped into the water with the aid of rope tied round each bottle.

Determination of Physico-chemical Parameters: Several physico-chemical parameters of the water samples from the five sampling points were determined once in a month. Parameters such as; $\mathrm{pH}$, Electrical conductivity, total dissolved solids, dissolved oxygen were determined using appropriate calibrated meters which included; $\mathrm{pH}$ meter, EC meter, TDS meter and DO meter. Turbidity was evaluated with the aid of a visible spectrophotometer. The salinity and bicarbonate parameters were determined according to procedures described by Radojevic and Bashkin (1999). Calcium, magnesium and the heavy metals; $\mathrm{Fe}, \mathrm{Zn}, \mathrm{Cd}, \mathrm{Pb}$ and $\mathrm{Cu}$ were evaluated using a Flame photometer and Atomic absorbance spectrophotometer respectively. Alkalinity, chloride and total hardness were evaluated using titrimeteric procedures as described by Radojevic and Bashkin (1999). Nitrate and sulphate parameters were determined using colorimetric methods as described by Ogbeibu et al. (2014). The BOD and COD parameters were ascertained using modified Wrinklers procedure and dichromate method as described by Ogbeibu et al. (2014). The phosphate value of the samples was determined using ascorbic acid method as described by APHA (1998). The temperature readings of the sampled surface water were determined with the aid of a graduated mercuryin-glass thermometer. The TSS parameter was evaluated with the aid of gravimeteric procedure as described by Ogbeibu et al. (2014).

Determination of the Water Quality Index (WQI): The data obtained from the physicochemical characteristics in water was subjected to Water Quality Index modeling as described by Ramakrishniah et al. (2009).

Statistical Analysis: Statistical analysis was carried out on the data generated from each sampling station using general descriptive statistics. The student $\mathrm{T}$ test and Kruskel Wallis Test was also used to test for significance at the 0.05 level of probability for the seasons and the different stations respectively. Multivariate analysis of the available data was done using the SPSS version 16.0 and PAST software whilst Duncan's Multiple Range test (DMR) was used to locate significant difference(s) at $95 \%$ confidence Interval where one exist.

\section{RESULTS AND DISCUSSION}

The results of the physicochemical parameters for the water samples obtained separately from the five sampling stations in Falcorp mangrove swamp are shown in Table 1A. The results showed that there was no significant difference $(P>0.05)$ across the stations (Stations 1, 2, 3, 4 and 5) respectively for $\mathrm{pH}$, Temperature, Electrical conductivity, DO, BOD5, TSS, Turbidity, Chloride, Salinity, Sulphate, Nitrate, Hardness, Calcium, Magnesium, Zinc, Cadmium and Lead, while there was significant difference $(P<0.05)$ across the 5 stations for the following parameters; TDS, Bi-carbonate, Phosphate, Iron and Copper. The mean concentrations of most of the physical and chemical parameters in the surface water with the exception of $\mathrm{pH}$ were below acceptable WHO limits for portable water. 
Table 1a: Summary results of physicochemical properties of five stations, in Falcorp Mangrove within the period; February 2013- July

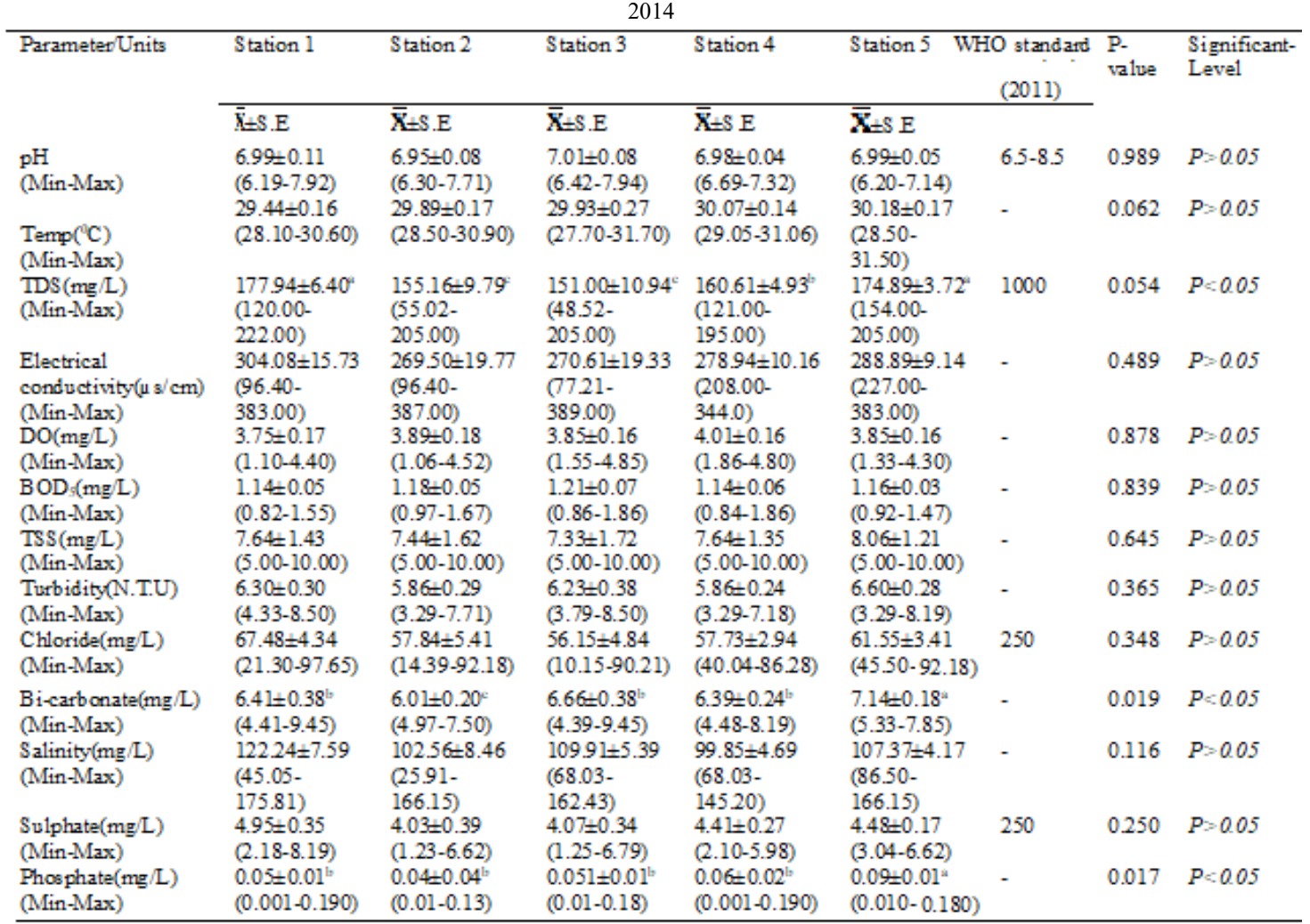

Key $: \bar{x} \pm$ S.E - Mean \pm Standard error, $P>0.05$ - Indicated no significant difference and $P<0.05$ - indicated significant difference

Table 1b: Summary results of physicochemical properties of the sampled five stations, in Falcorp Mangrove, within the period; February

\begin{tabular}{|c|c|c|c|c|c|c|c|c|}
\hline Parametexunits & Station 1 & Station 2 & Station 3 & Station 4 & Station 5 & $\begin{array}{l}\text { WHO } \\
\text { stand ard } \\
(2011)\end{array}$ & $\begin{array}{l}\text { P. } \\
\text { value }\end{array}$ & $\begin{array}{l}\text { Significant- } \\
\text { Level }\end{array}$ \\
\hline & $? \pm$ S.E & $? \pm$ S.E & $? \pm$ S.E & $? \pm$ S.E & $? \pm$ S.E & & & \\
\hline $\begin{array}{l}\text { Nitrate(mg/L) } \\
\text { (Min-Max) }\end{array}$ & $\begin{array}{l}0.54=0.05 \\
(0.18-0.97)\end{array}$ & $\begin{array}{l}0.49 \pm 0.07 \\
(0.11-0.88)\end{array}$ & $\begin{array}{l}0.62 \pm 0.05 \\
(0.19-0.96)\end{array}$ & $\begin{array}{l}0.54 \pm 0.06 \\
(0.19-0.97)\end{array}$ & $\begin{array}{l}0.62 \pm 0.05 \\
(0.18-0.96)\end{array}$ & 50 & 0.445 & $P=0.05$ \\
\hline $\begin{array}{l}\text { Hardness ('dH) } \\
\text { (Min-Max) }\end{array}$ & $\begin{array}{l}9.61=0.54 \\
(7.00-15.00)\end{array}$ & $\begin{array}{l}8.22 \pm 0.54 \\
(5.00-12.00)\end{array}$ & $\begin{array}{l}8.36 \pm 0.67 \\
(3.00-15.00)\end{array}$ & $\begin{array}{l}7.89=0.36 \\
(5.00-10.00)\end{array}$ & $\begin{array}{l}8.65 \pm 0.32 \\
(5.00-12.00)\end{array}$ & 200 & 0.156 & $P=0.05$ \\
\hline $\begin{array}{l}\text { Calcium (mg/L) } \\
\text { (Min-Max }\end{array}$ & $\begin{array}{l}2.68=0.15 \\
(1.08-3.53)\end{array}$ & $\begin{array}{l}2.23 \pm 0.21 \\
(1.05-3.63)\end{array}$ & $\begin{array}{l}2.35 \pm 0.22 \\
(1.11-4.22)\end{array}$ & $\begin{array}{l}2.27 \pm 0.15 \\
(1.32-3.12)\end{array}$ & $\begin{array}{l}2.31 \pm 0.08 \\
(1.69-3.12)\end{array}$ & - & 0.348 & $P=0.05$ \\
\hline $\begin{array}{l}\text { Magnesium(mg/L) } \\
\text { (Min-Max) }\end{array}$ & $\begin{array}{l}1.37 \pm 0.11 \\
(0.40-1.98)\end{array}$ & $\begin{array}{l}1.16 \pm 0.13 \\
(0.19-1.98)\end{array}$ & $\begin{array}{l}1.11=0.13 \\
(0.33-2.22)\end{array}$ & $\begin{array}{l}1.07 \pm 0.13 \\
(0.19-1.83)\end{array}$ & $\begin{array}{l}1.25 \pm 0.09 \\
(0.27-1.85)\end{array}$ & - & 0.436 & $P=0.05$ \\
\hline $\begin{array}{l}\text { Iron(mg/L) } \\
\text { (Min-Max) }\end{array}$ & $\begin{array}{l}0.01 \pm 0.00 \\
(0.001-0.024)\end{array}$ & $\begin{array}{l}0.01=0.00^{\circ} \\
(0.00-0.02)\end{array}$ & $\begin{array}{l}0.01=0.00^{b} \\
(0.00-0.03)\end{array}$ & $\begin{array}{l}0.00=0.00^{\circ} \\
(0.00-0.01)\end{array}$ & $\begin{array}{l}0.01 \pm 0.00^{\circ} \\
(0.00-0.03)\end{array}$ & - & 0.044 & $P<0.05^{*}$ \\
\hline Zinc $(m g / L)$ & $0.19=0.03$ & $0.14=0.02$ & $0.14 \pm 0.02$ & $0.14=0.02$ & $0.13=0.01$ & - & 0.247 & $P=0.05$ \\
\hline (Min-Max) & $(0.04-0.42)$ & $(0.02-0.30)$ & $(0.03-0.29)$ & $(0.01-0.42)$ & $(0.06-0.30)$ & & & \\
\hline $\begin{array}{l}\text { Copper(mg/L) } \\
\text { (Min-Max) }\end{array}$ & $\begin{array}{l}0.01=0.00^{\circ} \\
(0.00-0.02)\end{array}$ & $\begin{array}{l}0.01=0.00 \\
(0.00-0.02)\end{array}$ & $\begin{array}{l}0.00 \pm 0.00^{\circ} \\
(0.00-0.01)\end{array}$ & $\begin{array}{l}0.00 \pm 0.00^{\circ} \\
(0.00-0.02)\end{array}$ & $\begin{array}{l}0.01 \div 0.00^{b} \\
(0.00-0.01)\end{array}$ & - & 0.054 & $P<005$ \\
\hline $\begin{array}{l}\text { Cadmivm }(\operatorname{mg} / L) \\
(\mathrm{Min}-\mathrm{Max})\end{array}$ & $\begin{array}{l}0.00 \pm 0.00 \\
(0.00-0.00)\end{array}$ & $\begin{array}{l}0.00 \pm 0.00 \\
(0.00-0.00)\end{array}$ & $\begin{array}{l}0.00 \pm 0.00 \\
(0.00-0.00)\end{array}$ & $\begin{array}{l}0.00=0.00 \\
(0.00-0.00)\end{array}$ & $\begin{array}{l}0.00 \pm 0.00 \\
(0.00-0.00)\end{array}$ & - & 0.604 & $P=0.05$ \\
\hline $\begin{array}{l}\text { Lead }(\mathrm{mg} / \mathrm{L}) \\
\text { (Min-Max) }\end{array}$ & $\begin{array}{l}0.00=0.00 \\
(0.00-0.00)\end{array}$ & $\begin{array}{l}0.00 \pm 0.00 \\
(0.001-0.001)\end{array}$ & $\begin{array}{l}0.00=0.00 \\
(0.00-0.00)\end{array}$ & $\begin{array}{l}0.00=0.00 \\
(0.00-0.00)\end{array}$ & $\begin{array}{l}0.00 \pm 0.00 \\
(0.00-0.00)\end{array}$ & - & 0.085 & $P=0.05$ \\
\hline
\end{tabular}

KEY : $\bar{x} \pm$ S.E - Mean \pm Standard error, $P>0.05$ - Indicated no significant difference and $P<0.05$ - indicated significant difference

Seasonal variation (wet season and dry season) of the various physicochemical parameters of the water samples is shown in Table 2. The $\mathrm{pH}, \mathrm{EC}$, Sulphate,
Hardness, Calcium, Magnesium, Iron, Zinc and Copper were compared between dry season and wet season respectively. The analysis results showed that 
there was very highly significant difference $(\mathrm{P}<0.001)$ across the study stations. Followed by TDS, DO, Chloride, Salinity and phosphate showed highly significant difference $(P<0.01)$, TSS, Turbidity, Bicarbonate and Cadmium showed significant difference $(P<0.05)$, while the results obtained for Temperature, $\mathrm{BOD}_{5}$, Nitrate, and Lead were also compared across the study area and revealed that there was no significant difference $(P>0.05)$. The mean hydrogen ion concentration $(\mathrm{pH})$ was slightly acidic throughout the study period in all the stations. There was no significant difference $(p>0.5)$ in the $\mathrm{pH}$ content of the water samples between stations. The fluctuations in $\mathrm{pH}$ values in the different seasons of the year could be ascribed to factors like removal of $\mathrm{CO}_{2}$ by photosynthesis through bicarbonate degradation, dilution of river with fresh water, reduction in salinity and temperature, and decomposition of organic matter. The role of $\mathrm{pH}$ in water quality assessment is of immense importance to the health status of any aquatic system (Wang et al., 2007). Water temperature was relatively high throughout the sampling period varying from $29.92 \pm 0.14$ to $30.02 \pm 0.11^{\circ} \mathrm{C}$. The temperature was characterised by relatively stable regime throughout the sampling period and there was no significant difference $(\mathrm{p}>0.05)$ between the seasons. Water temperature was lower in the dry season than in the rainy season. A possible principal reason for this trend is that these regions are usually close to the equator and usually are characterised by a fairly stable and constant temperature regimes with variations as you transcend further away from the equatorial region. The results obtained for water temperature was consistent with the study of Dirisu and Olomukoro (2015). Conductivity values in the mangrove water were higher in the rainy season than dry season and the difference between the seasons was highly significant $(p>0.0001)$. The high values of conductivity recorded during the early periods of the rainy season could be due to the influx of eroded sediment as a result of the flooding of the swamp bank.

Table 2: Summary of the seasonal variations in the physicochemical data of surface water sampled from the respective stations in Falcorp Mangrove, within the period; February 2013- July 2014

\begin{tabular}{|c|c|c|c|c|}
\hline \multirow[t]{2}{*}{ Parameter/units } & Dry season & Wet season & \multirow[t]{2}{*}{ P-value } & \multirow[t]{2}{*}{ Significance Level } \\
\hline & $\overline{\mathbf{X}}+$ S.E & $\overrightarrow{\mathrm{I}} \pm$ S.E & & \\
\hline $\mathrm{pH}$ & $6.8269 \pm 0.049$ & $7.086 \pm 0.039$ & 0.000 & $P<0.001 * * *$ \\
\hline Temp $\left({ }^{\circ} \mathrm{C}\right)$ & $29.717 \pm 0.136$ & $30.021 \pm 0.108$ & 0.083 & $P>0.05$ \\
\hline $\operatorname{TDS}(\mathrm{mg} / \mathrm{L})$ & $151.420 \pm 6.734$ & $171.870 \pm 6.734$ & 0.004 & $P<0.01 * *$ \\
\hline $\operatorname{COND}(\mu \mathrm{s} / \mathrm{cm})$ & $243.260 \pm 10.807$ & $307.320 \pm 7.229$ & 0.000 & $P<0.001 * * *$ \\
\hline $\mathrm{DO}(\mathrm{mg} / \mathrm{L})$ & $3.588 \pm 0.166$ & $4.048 \pm 0.041$ & 0.002 & $P<0.01 * *$ \\
\hline $\mathrm{BOD}_{5}(\mathrm{mg} / \mathrm{L})$ & $1.211 \pm 0.038$ & $1.139 \pm 0.027$ & 0.118 & $P>0.05$ \\
\hline $\mathrm{TSS}(\mathrm{mg} / \mathrm{L})$ & $7.214 \pm 0.279$ & $7.882 \pm 0.173$ & 0.034 & $P<0.05^{*}$ \\
\hline Turbidity ( N.T.U) & $5.845 \pm 0.256$ & $6.378 \pm 0.146$ & 0.055 & $P<0.05^{*}$ \\
\hline Chloride (mg/L) & $52.850 \pm 3.077$ & $64.403 \pm 0.164$ & 0.002 & $P<0.01 * *$ \\
\hline Bi-carbonate $(\mathrm{mg} / \mathrm{L})$ & $6.763 \pm 0.183$ & $6.763 \pm 0.183$ & 0.021 & $P<0.05^{*}$ \\
\hline Salinity $(\mathrm{mg} / \mathrm{L})$ & $98.967 \pm 4.476$ & $114.380 \pm 3.529$ & 0.008 & $P<0.01$ ** \\
\hline Sulphate $(\mathrm{mg} / \mathrm{L})$ & $3.802 \pm 0.210$ & $4.761 \pm 0.173$ & 0.001 & $P<0.001 * * *$ \\
\hline Phosphate (mg/L) & $0.080 \pm 0.009$ & $0.048 \pm 0.007$ & 0.006 & $P<0.01 * *$ \\
\hline Nitrate $(\mathrm{mg} / \mathrm{L})$ & $0.563 \pm 0.039$ & $0.564 \pm 0.034$ & 0.991 & $P>0.05$ \\
\hline Hardness $\left({ }^{\circ} \mathrm{dH}\right)$ & $7.439 \pm 0.314$ & $9.250 \pm 0.279$ & 0.000 & $P<0.001 * * *$ \\
\hline Calcium (mg/L) & $2.019 \pm 0.109$ & $2.587 \pm 0.091$ & 0.000 & $P<0.001 * * *$ \\
\hline Magnesium (mg/L) & $0.927 \pm 0.085$ & $1.359 \pm 0.061$ & 0.000 & $P<0.001 * * *$ \\
\hline Iron (mg/L) & $0.012 \pm 0.001$ & $0.006 \pm 0.001$ & 0.000 & $P<0.001 * * *$ \\
\hline Zinc $(\mathrm{mg} / \mathrm{L})$ & $0.209 \pm 0.017$ & $0.108 \pm 0.009$ & 0.000 & $P<0.001 * * *$ \\
\hline Copper (mg/L) & $0.008 \pm 0.001$ & $0.004 \pm 0.001$ & 0.001 & $P<0.001 * * *$ \\
\hline Cadmium (mg/L) & $0.001 \pm 0.000$ & $0.001 \pm 0.000$ & 0.027 & $P<0.05^{*}$ \\
\hline Lead $(\mathrm{mg} / \mathrm{L})$ & $0.001 \pm 0.000$ & $0.001 \pm 0.000$ & 0.074 & $P>0.05$ \\
\hline
\end{tabular}

Table 3: The summary of the water quality index (WQI) of Falcorp Mangrove swamp

\begin{tabular}{llllll}
\hline Stations & Mean & SD & Min & Max & Benchmark \\
\hline 1 & 10.69 & 4.16 & 8.45 & 24.19 & \\
2 & 9.66 & 3.59 & 8.31 & 23.95 & \\
3 & 9.44 & 2.46 & 8.36 & 16.26 & 100.00 \\
4 & 8.64 & 0.51 & 8.24 & 10.11 & \\
5 & 10.12 & 3.79 & 8.43 & 23.58 & \\
\hline
\end{tabular}

NB: All valves were considered suitable (fit), < than the benchmark 100; the interpretations of Ramakrishniah et al. (2009)

ODIGIE, O; OLOMUKORO, JO 


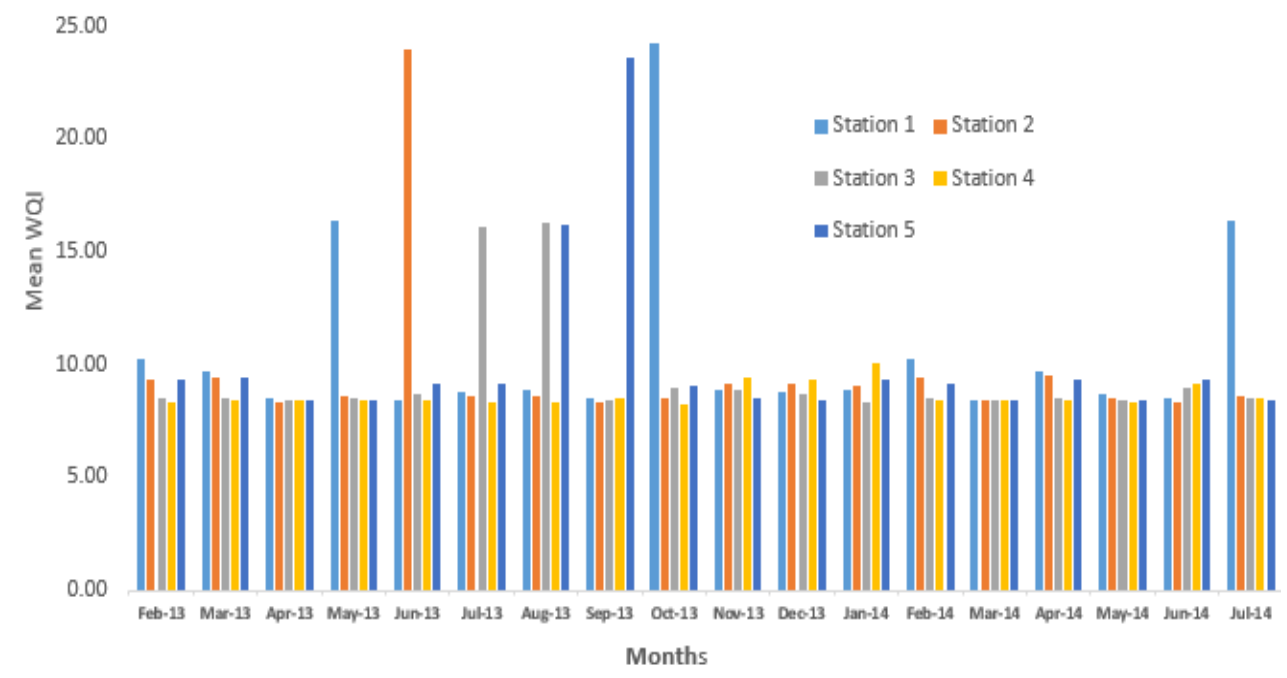

Fig. 1: Spatial and monthly variations of the WQI in Falcorp mangrove swamp

This event usually leads to increase in the physicochemical properties of water. This was particularly noticed in from early April through September as a result of the heavy precipitation that occurred. This incidence (heavy rainfall) resulted to silting of the swamp with the consequent over flooding of the bank. Tropical aquatic ecosystem should have dissolved oxygen concentration of at least $5 \mathrm{mgl}^{-1}$ in order to support biotic diversity (Radojevic and Bashkin, 1999; Wakawa et al., 2008). The mean dissolved oxygen values in this study were higher $(4.05 \mathrm{mg} / \mathrm{L})$ during the wet season when compared with the mean value $(3.59 \mathrm{mg} / \mathrm{L})$ obtained during the dry season. The DO values obtained in this study were lower compared to the values proposed by Radojevic and Bashkin, (1999) and Wakawa et al., (2008). This might raise serious concern for the health status of this aquatic ecosystem. Season-wise observation of dissolved oxygen showed a direct trend with temperature and salinity in this season. Temperature and salinity are known to impact dissolved oxygen dissolution in aquatic ecosystem.

The total dissolved solids (TDS) and total suspended solids (TSS) values obtained in this study were less than WHO critical limits of $2000 \mathrm{mg} / \mathrm{L}$ and $1700 \mathrm{mg} / \mathrm{L}$ respectively for drinking water. In the rainy season, the TSS value was slightly higher consequent to floating materials like fine silt carried by rainwater.

The Biochemical oxygen demand $\left(\mathrm{BOD}_{5}\right)$ maximal value; $1.18 \mathrm{mg} / \mathrm{L}$ in both seasons was relatively low in comparison with the WHO prescribed limit of 7.0 $\mathrm{mg} / \mathrm{L}$. Low oxygen in water can negatively impact the lives of obligate aerobic aquatic organisms such as fish, crab and other invertebrates. This could be attributed to entrance of high organic materials from the anthropogenic activities within that stretch of the swamp. This is also similar with the findings of Anyanwu, (2012).

The exchangeable cations $\left(\mathrm{Ca}^{2+}\right.$ and $\left.\mathrm{Mg}^{2+}\right)$ in this study generally showed a marked similarity in the pattern of fluctuation. The slight increment in the concentration of the exchangeable cations of the surface water was as a result of dry season evaporation factor. All the five stations showed nearly the similar value of total hardness throughout the period of sampling. Maximum value of total hardness was observed in the wet season. There was no significant difference $(p>0.05)$ across the sampling stations. However it was way below the standard value for total hardness which is $300^{\circ} \mathrm{dH}$.

The anions $\left(\mathrm{Cl}^{-}, \mathrm{HCO}_{3}^{-}, \mathrm{NO}_{3}^{2-}\right.$, and $\left.\mathrm{SO}_{4}^{2-}\right)$ also followed a similar fluctuation pattern. Although, concentration was higher in the rainy season, there was no significant difference $(\mathrm{p}>0.05)$ between the stations but the seasons $(p<0.001)$. The higher concentration of anions in Falcorp mangrove in the rainy season could be attributed to the influx of eroded materials from the surrounding terrestrial areas and dead decaying vegetation and detritus washed down by early rain. Increase in water sulphate contents during the rainy season may be attributed to increase in influx of sulphate from sulphate fertilizers from farm lands. This finding contrasted with that of Dirisu and Olomukoro, (2015) who reported slightly high values in Agbede wetland, southern Nigeria.

All the heavy metals detected in this study were in trace concentrations. Metals detected occurred in the 
following order; $\mathrm{Zn}>\mathrm{Fe}>\mathrm{Cu}=\mathrm{Cd}>\mathrm{Pb}$. The presence of heavy metals in the aquatic environment is a major concern because of their toxicity and threat to plant and animal life, thus disturbing the natural ecological balance (Bhattacharya et al., 2008). All the heavy metals were far lower than the WHO stipulated limits for surface water. These differences are of importance because of the dangers associated with heavy metal in our environment (Bakare-Odunola, 2005; Ibemenuga, 2013). The relatively elevated levels of heavy metals recorded in this aquatic ecosystem maybe from anthropogenic and farming activities situated close to this aquatic body washed down via runoff. This is in consonance with works of Naveedullah et al., (2013 and 2014).

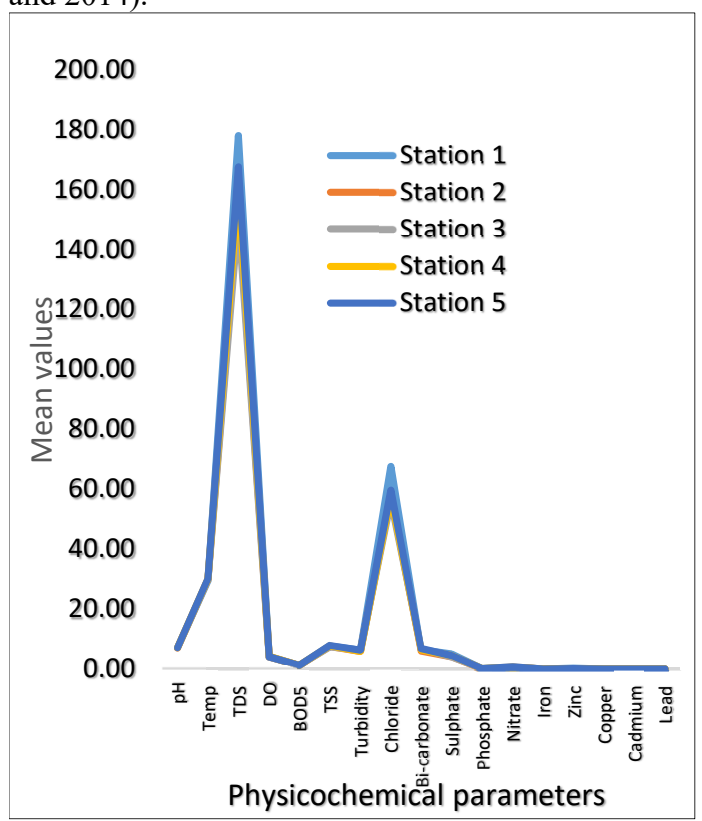

Fig. 2. Mean values of the physicochemical parameters influencing the WQI in Falcorp mangrove swamp

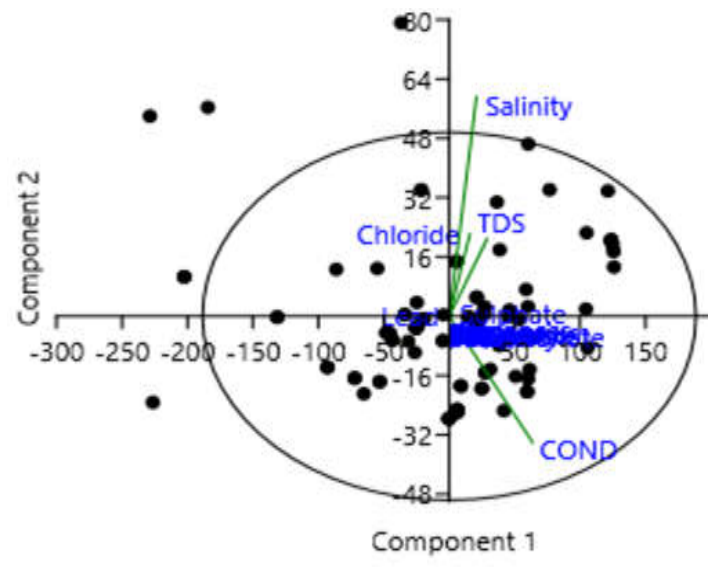

Fig. 3: Scatter plot for the physicochemical attributes of the water samples collected from Falcorp mangrove

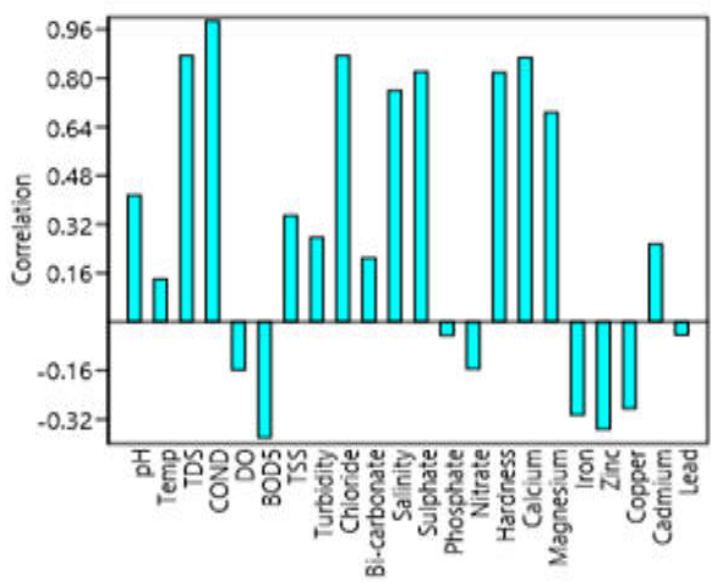

Fig. 4: Correlation graph for the respective physicochemical parameters

Table 3 revealed the summary of Water Quality Index (WQI) for stations 1-5 of Falcorp mangrove swamp. From the results, the water quality index at stations 1, $2,3,4$ and 5 ranged from $8.45-24.9,8.31-23.95,8.36-$ $16.26,8.24-10.11$ and $8.43-23.58$ respectively. The mean values of the WQI in stations $1,2,3,4$ and 5 were $10.69,9.66,9.44,8.64$ and 10.12 respectively.

Figures 1 and 2 showed the spatial and monthly variations of the WQI across the four stations and the parameters that influenced the WQI respectively. It was observed that in all the months (February 2013 July 2014), the WQI were very lower than the benchmark (100). Low TDS and $\mathrm{Cl}$ in stations 4 and 5 might have contributed to the low WQI in this ecosystem.

Water quality index has been utilized in the designation of water quality which denotes the general worth of water for any purpose (Etim et al., 2012). The WQI in this study revealed that in all the sampling months (February 2013 - July 2014), there were lower values compared to the benchmark (100). Low TDS and $\mathrm{Cl}$ in stations 4 and 5 might have contributed to the low WQI in this ecosystem. TDS had the potential to increase in the ecosystem if the stations are perturbed by anthropogenic activities or by natural process; erosion.

The results indicated that the different surface water samples analysed from the five stations in Falcorp mangrove swamp were safe for human consumption and for other domestic purposes as at the time of this study. Low WQI values has widely been documented by several researchers; Shrestha and Kazama (2007); Ashwani and Anish, (2009); Khwakaram et al., (2012). 
Table 4: Eigenvectors and Eigenvalues of the various heavy metal components in the surface water parameters of Falcorp mangrove swamp sampled from February 2013- July 2014

\begin{tabular}{|c|c|c|c|c|c|c|c|c|c|c|c|}
\hline Parameters & $\mathrm{PC} 1$ & $\mathrm{PC} 2$ & $\mathrm{PC} 3$ & $\mathrm{PC} 4$ & PC 5 & $\mathrm{PC} 6$ & $\mathrm{PC} 7$ & PC 8 & PC 9 & $\mathrm{PC} 10$ & PC 11 \\
\hline$\overline{\mathrm{pH}}$ & 0.00 & 0.00 & 0.00 & 0.00 & 0.02 & -0.06 & 0.12 & 0.05 & -0.07 & 0.02 & 0.15 \\
\hline Temp & 0.00 & -0.01 & 0.00 & -0.01 & 0.04 & 0.17 & -0.04 & 0.80 & 0.45 & 0.29 & -0.08 \\
\hline TDS & 0.39 & 0.20 & 0.86 & -0.25 & -0.03 & -0.01 & -0.01 & 0.00 & 0.00 & 0.00 & 0.00 \\
\hline $\mathrm{EC}$ & 0.85 & -0.43 & -0.29 & -0.02 & -0.01 & -0.01 & -0.01 & -0.01 & 0.00 & 0.00 & 0.00 \\
\hline DO & 0.00 & 0.00 & -0.01 & 0.00 & -0.02 & -0.01 & 0.01 & 0.13 & 0.13 & 0.14 & 0.40 \\
\hline BOD5 & 0.00 & 0.00 & 0.00 & 0.00 & 0.00 & -0.02 & -0.03 & 0.00 & -0.03 & 0.06 & -0.25 \\
\hline TSS & 0.01 & -0.02 & 0.02 & 0.01 & 0.67 & -0.08 & -0.33 & -0.21 & 0.53 & -0.33 & 0.03 \\
\hline Turbidity & 0.00 & -0.01 & 0.02 & -0.01 & 0.59 & -0.04 & -0.28 & 0.21 & -0.64 & 0.33 & 0.04 \\
\hline Chloride & 0.21 & 0.31 & 0.10 & 0.92 & 0.01 & 0.00 & 0.02 & 0.02 & -0.01 & 0.00 & -0.01 \\
\hline Bi-carbonate & 0.00 & -0.02 & 0.01 & -0.02 & 0.29 & -0.60 & 0.70 & 0.17 & 0.02 & -0.10 & -0.09 \\
\hline Salinity & 0.27 & 0.82 & -0.40 & -0.29 & 0.01 & -0.03 & -0.02 & 0.01 & 0.01 & 0.00 & -0.01 \\
\hline Sulphate & 0.01 & 0.01 & 0.01 & 0.00 & 0.16 & 0.16 & 0.29 & -0.44 & 0.24 & 0.68 & 0.29 \\
\hline Phosphate & 0.00 & 0.00 & 0.00 & 0.00 & 0.00 & -0.01 & 0.01 & -0.01 & 0.00 & 0.04 & 0.01 \\
\hline Nitrate & 0.00 & 0.00 & 0.00 & -0.01 & 0.03 & 0.02 & 0.04 & 0.06 & 0.02 & -0.04 & 0.25 \\
\hline Hardness & 0.02 & 0.01 & 0.00 & -0.02 & 0.29 & 0.75 & 0.46 & 0.03 & -0.12 & -0.27 & -0.17 \\
\hline Calcium & 0.01 & 0.01 & 0.00 & 0.00 & -0.02 & 0.06 & -0.01 & 0.14 & -0.08 & -0.25 & 0.50 \\
\hline Magnesium & 0.00 & 0.01 & 0.00 & 0.00 & -0.01 & 0.02 & 0.07 & 0.12 & -0.11 & -0.25 & 0.56 \\
\hline Iron & 0.00 & 0.00 & 0.00 & 0.00 & 0.00 & 0.00 & 0.00 & 0.00 & 0.00 & 0.00 & 0.00 \\
\hline Zine & 0.00 & 0.00 & 0.00 & 0.00 & -0.01 & 0.00 & -0.01 & -0.02 & -0.02 & 0.02 & -0.04 \\
\hline Copper & 0.00 & 0.00 & 0.00 & 0.00 & 0.00 & 0.00 & 0.00 & 0.00 & 0.00 & 0.00 & 0.00 \\
\hline Cadmivm & 0.00 & 0.00 & 0.00 & 0.00 & 0.00 & 0.00 & 0.00 & 0.00 & 0.00 & 0.00 & 0.00 \\
\hline Lead & 0.00 & 0.00 & 0.00 & 0.00 & 0.00 & 0.00 & 0.00 & 0.00 & 0.00 & 0.00 & 0.00 \\
\hline $\mathrm{E}$ igenvalue & 5745.76 & 386.86 & 319.15 & 47.38 & 3.10 & 1.69 & 0.99 & 0.62 & 0.42 & 0.30 & 0.13 \\
\hline$\%$ variance & 88.31 & 5.95 & 491 & 0.73 & 0.05 & 0.03 & 0.02 & 0.01 & 0.01 & 0.00 & 0.00 \\
\hline
\end{tabular}

Table 4 Continue: Eigenvectors and Eigenvalues of the various heavy metal components in the surface water parameters of Falcorp mangrove swamp sampled from February 2013- July 2014

\begin{tabular}{|c|c|c|c|c|c|c|c|c|c|c|c|}
\hline Parameters & $\mathrm{PC} 12$ & PC 13 & $\mathrm{PC} 14$ & PC 15 & PC 16 & PC 17 & $\mathrm{PC} 18$ & PC 19 & PC 20 & PC 21 & $\mathrm{PC} 22$ \\
\hline$\overline{\mathrm{pH}}$ & -0.26 & 0.67 & 0.00 & 0.09 & 0.65 & 0.02 & -0.01 & 0.01 & 0.00 & 0.00 & 0.00 \\
\hline Temp & -0.10 & -0.05 & -0.16 & 0.00 & 0.04 & 0.01 & 0.00 & 0.00 & 0.00 & 0.00 & 0.00 \\
\hline $\operatorname{TDS}$ & 0.00 & 0.01 & 0.01 & 0.00 & 0.00 & 0.00 & 0.00 & 0.00 & 0.00 & 0.00 & 0.00 \\
\hline $\mathrm{EC}$ & 0.00 & 0.00 & 0.00 & 0.00 & 0.00 & 0.00 & 0.00 & 0.00 & 0.00 & 0.00 & 0.00 \\
\hline DO & 0.52 & 0.36 & 0.56 & -0.14 & -0.24 & 0.03 & -0.01 & 0.00 & 0.00 & 0.00 & 0.00 \\
\hline BOD5 & 0.25 & 0.30 & -0.16 & 0.83 & -0.27 & 0.01 & -0.01 & 0.00 & 0.00 & 0.00 & 0.00 \\
\hline TSS & 0.01 & 0.07 & -0.02 & 0.02 & 0.03 & 0.02 & 0.01 & 0.00 & 0.00 & 0.00 & 0.00 \\
\hline Turbidity & 0.00 & -0.04 & 0.01 & -0.04 & -0.03 & -0.01 & -0.01 & 0.00 & 0.00 & 0.00 & 0.00 \\
\hline Chloride & 0.00 & 0.00 & 0.00 & 0.00 & 0.01 & 0.00 & 0.00 & 0.00 & 0.00 & 0.00 & 0.00 \\
\hline Bi-carbonate & -0.01 & -0.07 & 0.03 & -0.02 & -0.11 & 0.02 & 0.00 & 0.00 & 0.00 & 0.00 & 0.00 \\
\hline Salinity & 0.00 & 0.00 & 0.00 & 0.00 & 0.00 & 0.00 & 0.00 & 0.00 & 0.00 & 0.00 & 0.00 \\
\hline Sulphate & -0.13 & -0.07 & -0.18 & 0.07 & -0.07 & 0.00 & -0.03 & 0.00 & 0.00 & 0.00 & 0.00 \\
\hline Phosphate & 0.05 & -0.01 & -0.02 & 0.01 & 0.04 & 0.07 & 0.99 & -0.04 & 0.00 & 0.00 & 0.00 \\
\hline Nitrate & 0.15 & -0.55 & 0.36 & 0.47 & 0.50 & -0.06 & -0.03 & 0.01 & 0.00 & 0.00 & 0.00 \\
\hline Hardness & 0.08 & 0.06 & 0.10 & -0.03 & -0.02 & 0.01 & 0.01 & 0.00 & 0.00 & 0.00 & 0.00 \\
\hline Calcium & -0.63 & 0.00 & 0.15 & 0.24 & -0.42 & 0.09 & 0.05 & 0.00 & 0.00 & 0.00 & 0.00 \\
\hline Magnesium & 0.38 & -0.03 & -0.67 & -0.04 & 0.04 & 0.00 & -0.03 & 0.00 & 0.00 & 0.00 & 0.00 \\
\hline Iron & 0.00 & 0.00 & 0.00 & 0.00 & 0.00 & 0.02 & 0.04 & 0.89 & -0.44 & 0.00 & 0.01 \\
\hline Zine & 0.05 & -0.06 & -0.01 & 0.00 & 0.06 & 0.99 & -0.07 & -0.02 & -0.02 & 0.00 & 0.00 \\
\hline Copper & 0.00 & 0.00 & 0.00 & 0.00 & 0.00 & 0.03 & 0.02 & 0.44 & 0.89 & -0.02 & -0.02 \\
\hline Cadmium & 0.00 & 0.00 & 0.00 & 0.00 & 0.00 & 0.00 & 0.00 & 0.01 & 0.02 & 1.00 & 0.04 \\
\hline Lead & 0.00 & 0.00 & 0.00 & 0.00 & 0.00 & 0.00 & 0.00 & 0.00 & 0.03 & -0.04 & 1.00 \\
\hline $\mathrm{E}$ igenvalue & 0.07 & 0.06 & 0.05 & 0.02 & 0.02 & 0.00 & 0.00 & 0.00 & 0.00 & 0.00 & 0.00 \\
\hline$\%$ variance & 0.00 & 0.00 & 0.00 & 0.00 & 0.00 & 0.00 & 0.00 & 0.00 & 0.00 & 0.00 & 0.00 \\
\hline
\end{tabular}

NB: Bolded values exceeded standards. Loadings of $>0.71$ are typically regarded as excellent, and loadings $<0.32$ very poor. However, Nair et al., (2010) stated that the component with the highest Eigenvalue is taken to be the most significant and should be one or greater for proper considerations during PCA. Factor loadings values of $>0.75$, between $0.75-0.5$ and $0.5-0.3$ are classified as strong, moderate and weak respectively, based on their absolute values.

The result of the PCA based on the correlation matrix of the physical and chemical parameters was expressed in Table 4. The PCA was performed on the data sets containing 22 variables analysed in the water samples (Fig. 3). The PCA of the data sets yielded 35 variables under 22 components with Eigenvalues $<1$ (PC1-PC6) and >1 (PC7-PC22). These variables explained 99.79 and $0.04 \%$ of the total variance in water quality respectively. The contributions were as followed - component $1,2,3,4,5,6,7,8,9,10,11$, 
$12,13,14,15,16,17,18,19,20,21$ and 22 , accounted for the proportion as follows: 88.31, 5.76, 4.91, 0.73, $0.05,0.03,0.02,0.01,0.01,0.00,0.00,0.00,0.00$, $0.00,0.00,0.00,0.00,0.00,0.00,0.00,0.00$ and $0.00 \%$ respectively (Table 4). The parameters of importance in each component were: 1; TDS (0.39) and conductivity (0.85), 2; Salinity (0.82), 3; TDS (0.86), 4; $\mathrm{Cl}(0.92), 5$; Turbidity $(0.59), 6$; hardness $(0.75), 7$; $\mathrm{HCO}_{3}$ and hardness $(0.70$ and 0.46$)$ 8; water temperature $(0.80), 9$; water temperature and TSS (0.45 and 0.53), 10; $\mathrm{SO}_{4}(0.68), 11 ; \mathrm{DO}, \mathrm{Ca}$ and $\mathrm{Mg}$ $(0.40,0.50$ and 0.56$), 12 ; \mathrm{DO}$ and $\mathrm{Mg}(0.52$ and 0.38$)$, 13; $\mathrm{pH}, \mathrm{DO}$ and BOD5 (0.67, 0.36 and 0.30), 14; DO and $\mathrm{NO}_{3}(0.54$ and 0.36$), 15 ; \mathrm{BOD}_{5}$ and $\mathrm{NO}_{3}(0.83$ and 0.47), 16; $\mathrm{pH}$ and $\mathrm{NO}_{3}$ (0.65 and 0.50), 17; $\mathrm{Zn}(0.99)$, 18; $\mathrm{PO}_{4}$ (0.99), 19; $\mathrm{Fe}$ and $\mathrm{Cu}(0.89$ and 0.44), 20; $\mathrm{Cu}$ (0.89), 21; Cd (1.00) and 22; Pb (1.00) (Table 4). In this study, $\mathrm{PC} 1, \mathrm{PC} 2$, and $\mathrm{PC} 3$ contributed the larger percentage $(88.31,5.76$ and $4.91 \%)$ respectively of the loadings of heavy metals in the surface water PCA. The parameters of importance in each component were PC1; TDS (0.39) and conductivity (0.85), PC2; Salinity (0.82) and PC3; TDS (0.86) respectively out of the 22 components. The source allotment could be traced from organic and inorganic pollution by man activities as the major point source of contamination (Vega et al., 1998; Simeonov et al., 2003; Liu et al., 2006; Wang et al., 2007).

The Eigenvalues in this study were $<1$ in PC1-PC6 and $>1$ in PC7-PC22; in all the PCA components. Eigenvalues of 1.0 or greater are considered significant (Shrestha and Kazama, 2007). By implication, the highest eigenvalue was regarded as been the most significant and should be one or greater for proper consideration during PCA (Nair et al., 2010). Factor loadings values of $>0.75$, between 0.5 0.75 and $0.3-0.5$ are classified as strong, moderate and weak respectively, based on their absolute values. The eigenvalues gotten in this study indicated PC1-PC6 to have strong absolute values and PC7-PC22 fall between moderate and weak absolute values. These also revealed that parameters in PC1-PC6 components had strong influence in the ecosystem and PC7-PC22 which had similar parameters as the latter, had slight significant influence in the same ecosystem.

Figure 3 revealed the scatter plot and the relationship of the physicochemical parameters in Falcorp mangrove swamp. There were cluster of salinity and TDS, $\mathrm{Cl}$ and $\mathrm{Pb}, \mathrm{SO}_{4}$ and Conductivity in components 1 and 2. The relationship of the parameters as shown in the scatter plot also indicate similar cluster between the following physicochemical parameters; salinity, $\mathrm{TDS}, \mathrm{Cl}, \mathrm{Pb}, \mathrm{SO}_{4}$ and Conductivity. However, positive correlation exist between $\mathrm{pH}$, water temperature, TDS, conductivity, TSS, turbidity, $\mathrm{Cl}, \mathrm{HCO}_{3}$, salinity, $\mathrm{SO}_{4}$, hardness, $\mathrm{Ca}, \mathrm{Mg}$, and $\mathrm{Cd}$, whilst a negative relationship exist between $\mathrm{DO}, \mathrm{BOD}_{5}, \mathrm{PO}_{4}, \mathrm{NO}_{3}, \mathrm{Fe}$, $\mathrm{Zn}, \mathrm{Cu}$ and $\mathrm{Pb}$ (Fig. 5). The implication of this, indicate strong interrelationship between the chemical constituents and the aquatic environment and their impacts negatively and positively.

Conclusion: This research documented the selected physicochemical constituent make up of several study sites on the Falcorp mangrove swamp biome. The findings of the observed concentration levels were low despite the plethora of anthropogenic activities occurring within the watershed of the estuarine habitat.

\section{REFERENCES}

Anyanwu, ED (2012). Physicochemical and Some Trace Metal Analysis of Ogba River, Benin City, Nigeria. Jordan J. Biol. Sci. 5(1): $47-54$.

Ashwani, K; Anish, D, (2009). Water quality index for assessment of water quality of river Ravi at Madhopur (India).Glob. J. Environ. Sci. 8 (1): 49 -57 .

Bakare-Odunola, MT (2005). Determination of some metallic impurities present in soft drinks marketed in Nigeria. Nig. J. Pharm. 4(1): 51-54

Dirisu, AR; Olomukoro, JO (2015). Investigation of Water Quality of two Rivers in Agbede Wetlands in Southern Nigeria. Glob. NEST J. $17(3): 451-462$

Etim, EE; Akpan, IU; Andrew, C; Edet, EJ (2012). Determination of water quality index of pipe borne water in Akwa Ibom State, Nigeria. Inter. J. Chem. Sci. 5(2):179-182.

Field, C; Osborn, J; Hoffman, L; Polsenberg, J; Ackerly, D; Berry J (1998). Mangrove biodiversity and ecosystem function. Glob. Ecol. Biogeo. Lett. 7: 3-14.

Furukawa, K; Wolanski, E; Mueller, H (1997). Currents and sediment transport in mangrove forests. Estuar. Coast. Shelf Sci. 44: 301-310

Ibemenuga, KN (2013). Bioaccumulation and toxic effects of some heavy metals in freshwater fishes. Animal Res. Inter. 10 (3): 1792 - 1798.

Khwakaram, AI; Majid, SN; Hama, NY (2012). Determination of water quality index (WQI) for 
Qalyasan stream in Sulaimani city/Kurdistan region of Iraq. Inter. J. Plant Animal Environ. Sci. 12:148-157.

Liu, YP; Wang, LH; Liu, W; Liu, QB (2006). Research of organic pollution's character in Songhua River. Environ. Sci. Manage. 31(3): 73-75

Nair, I.V; Singh, K; Arumugam, M; Gangadhar, K; Clarson, D (2010). Trace metal quality of Meenachil River at Kottayam, Kerala (India) by principal component analysis. World Appl. Sci. J. 9(10): $1100-1107$.

Naveedullah, HMZ; Yu, C; Shen, H; Duan, D; Shen, C; Lou, L; Chen, Y (2013). Risk Assessment of Heavy Metals Pollution in Agricultural Soils of Siling Reservoir Watershed in Zhejiang Province, China. BioMed Res. Inter. 5:30-40.

Naveedullah, HMZ; Yu, C; Shen, H; Duan, D; Shen, C; Lou, L; Chen, Y, (2014). Concentrations and Human Health Risk Assessment of Selected Heavy Metals in Surface Water of the Siling Reservoir Watershed in Zhejiang Province, China. Pol. J. Environ. Stud. 23(3): 801-811.

Ogbeibu, AE; Omoigberale, MO; Ezenwa, IM; Eziza, JO; Igwe, JO (2014). Using Pollution Load Index and Geoaccumulation Index for the Assessment of Heavy Metal Pollution and Sediment Quality of the Benin River, Nigeria. Nat. Environ. 2(1):1 -9 .

Radojevic, M; Bashkin, VN (1999). Practical Environmental Analysis. The Royal Society of Chemistry, Cambridge. P 466
Ramakrishnaiah, CR; Sadashivaiah, C; Ranganna, G (2009). Assessment of Water Quality Index for the Groundwater in Tumkur Taluk, Karnataka State, India. E-J. Chem. 6(2):523-530

Shrestha, S and Kazama, F, (2007). Assessment of surface water quality using multivariate statistical techniques: A case study of the Fuji river basin, Japan. Environ. Modell. Softw.22 (4): 464-475.

Simeonov, V; Stratis, JA; Samara, C; Zachariadis, G; Voutsa, D; Anthemidis, A; Sofoniou, M; Kouimtzis T (2003). Assessment of the surface water quality in Northern Greece. Water Res. 37 (17): 4119- 4124.

Vega, M; Pardo, R; Barrado, E; Debán, L (1998) Assessment of seasonal and polluting effects on the quality of river water by exploratory data analysis. Water Res. 32 (12): 3581-3592.

Wakawa, RJ; Uzairu, A; Kagbu, JA; Balarabe, ML (2008). Impact assessment of effluent discharge on physicochemical parameters and some heavy metal concentrations in surface water of River Challawa Kano, Nigeria. Afr. J. Pure Appl. Chem. 2(9):100-106

Wang, DH; Wang, Y; Lin, Z (2007). The control and damage of organic pollutant in Songhua River to the ecological environment. Environ. Sci. Manage. 32(6): 67-69 